\title{
The camera never lies
}

The partiality of photographic evidence

\section{Brian Winston}

Ten tijde van de ontdekking van de fotografie was het beeld nog oppermachtig. Zelfs de meest scherpzinnige geesten accepteerden in de negentiende eeuw bijna kritiekloos de foto als bewijs. Van de meeste wereldberoemde nieuwsfoto's is echter inmiddels vast komen te staan dat de erop afgebeelde 'werkelijkheid' in meer of mindere mate gemanipuleerd is door de maker. Voor vele beelden en scènes uit documentaires geldt hetzelfde. Welbeschouwd impliceert dat een bevrijding voor het realistische beeld. Niet langer hoeft dat een last te dragen die feitelijk altijd te zwaar is geweest. Maar het besef van het manipulatieve karakter impliceert tevens dat de culturele status van het (fotografische) beeld opnieuw vastgesteld moet worden.

Onderstaande tekst is een weergave van de lezing die Brian Winston hield op de voorjaarsconferentie van de Vereniging Geschiedenis Beeld en Geluid, 'De digitale revolutie en de geschiedenis van beeld en geluid', 23 mei 1997 in Hilversum.

To begin at the beginning: Here is François Arago in the French Chamber of Deputies, 3 July 1839:

'We do not hesitate to say that the reagents discovered by M. Daguerre will accelerate the progress of one of the sciences, which most honours the human spirit. With its aid the physicist will be able henceforth to proceed to the determination of absolute intensities; he will compare the various lights by their relative effect. ${ }^{\text {t }}$

Or here, a few weeks later on 30 July is the chemist Joseph Louis GayLussac in the French House of Peers, 30 July 1839:

'It is certain that through M. Daguerre's invention physics is today in possession of a reagent extraordinarily sensitive to the influence of light, a new instrument which will be to the study of the intensity of light and of luminous phenomena what the microscope is to the study of minute objects. ${ }^{\prime 2}$ 
I55 Years after Arago and Gay-Lussac successfully argued that the French nation should acquire the Daguerre patents for the world Labour Member, Andrew Bennett, rose in the House of Commons to request 'that leave be given to bring in a bill to require news media to prepare a code of practice to cover the principles by which pictures may be edited, altered and changed using computer techniques.' Bennett's request does not, however, signal how much more sophisticated we are today than we were at the time of photography's birth. On the contrary, the worry which brought him to his feet in the Commons speaks most powerfully to the persistence of the vision of Arago and Gay-Lussac. Bennett claims, with good reason, that "most people are aware of the old adage "the camera never lies". It seems to me that many people still believe it. (...) Most people believe pictures, particularly those accompanied by a well-respected voice on the television.' ${ }^{3}$

\section{Death mask}

Of course, in photography's founding moment, it was understood that photographs had artistic potential; but that was not the line taken by Arago and Gay-Lussac to persuade the government of the day to cough up a handsome annuity for Daguerre. Instead they positioned photography as science and located its social importance in its ability to produce evidence of all kinds of phenomena. This included evidence of the natural world (as with the suggestion that meteorological records could now include photographs of weather conditions), as well as man-made artefacts (as with the example that hieroglyphs could be more easily and accurately reproduced photographically than by any other means). In all this, the photographic process was almost hidden, its complexity a mere matter of necessary, mechanistic manoeuvres rather than an opportunity for human intervention and manipulation.

The result was that even the most acute of nineteenth century minds accepted uncritically the photograph as evidence. Charles Peirce, for example, felt photographs operated as a sort of death mask whereby the photographic plate was 'physically forced to correspond point by point to nature'. Thus photographs were a 'sign' of nature made 'by physical connection'. The French law also initially assumed no significant human intervention was involved in making a photograph. No question of intellectual property, nor therefore of copyright, could arise. It is scare any wonder that when, in the 1870 s, Dr Barnardo's famous 'before and after' photographs, showing the supposedly beneficent effects of his homes on an urchin, were revealed as having been taken on the same day an outrage 
cleric was moved to sue for public fraud. Or that, in the 1880 s, the Parisian policeman Alphonse Bertillon created a system of criminal identification based on measurements and photographic 'mug shots'.

Yet, from the outset, a certain cognitive dissonance also comes into play, conceding the limitations of photography's evidentiary power. Even as Bennett suggested people believed the old 'adage', he also acknowledged that this was 'in spite of the fact that many of them are aware that over the ages pictures have been faked'. It is possible that these two contradictory ideas about photography arise because faking, deliberate manipulation, is beyond our common experience. For most people, from the age of the Box Brownie to the era of the instant Polaroid and the camcorder, a photographic image is good evidence of the reality it captures. That is indeed how we looked on our day trip to the beach, when we were married, at our sixth birthday party. Bennett understands, as we all do, that this record might be partial: 'Perhaps there sits on the mantelpiece a photograph of Uncle Albert with a broad grin on his face, yet we know that, except for that one picture, he almost never grinned in his whole life'; ${ }^{7}$ but it is, nevertheless, a recognisable image of Uncle Albert. It is not 'faked'. We clicked the shutter on our automated camera; the chemist passed the film through the automated processor and out came Albert's image. The evidence is partial not because the photograph was tampered with at any stage but rather because, unusually, Albert was actually grinning when the shutter clicked.

1963 [?] Nieuw- en

St. Joosland.

Bron: Collectie Van

Haarlem

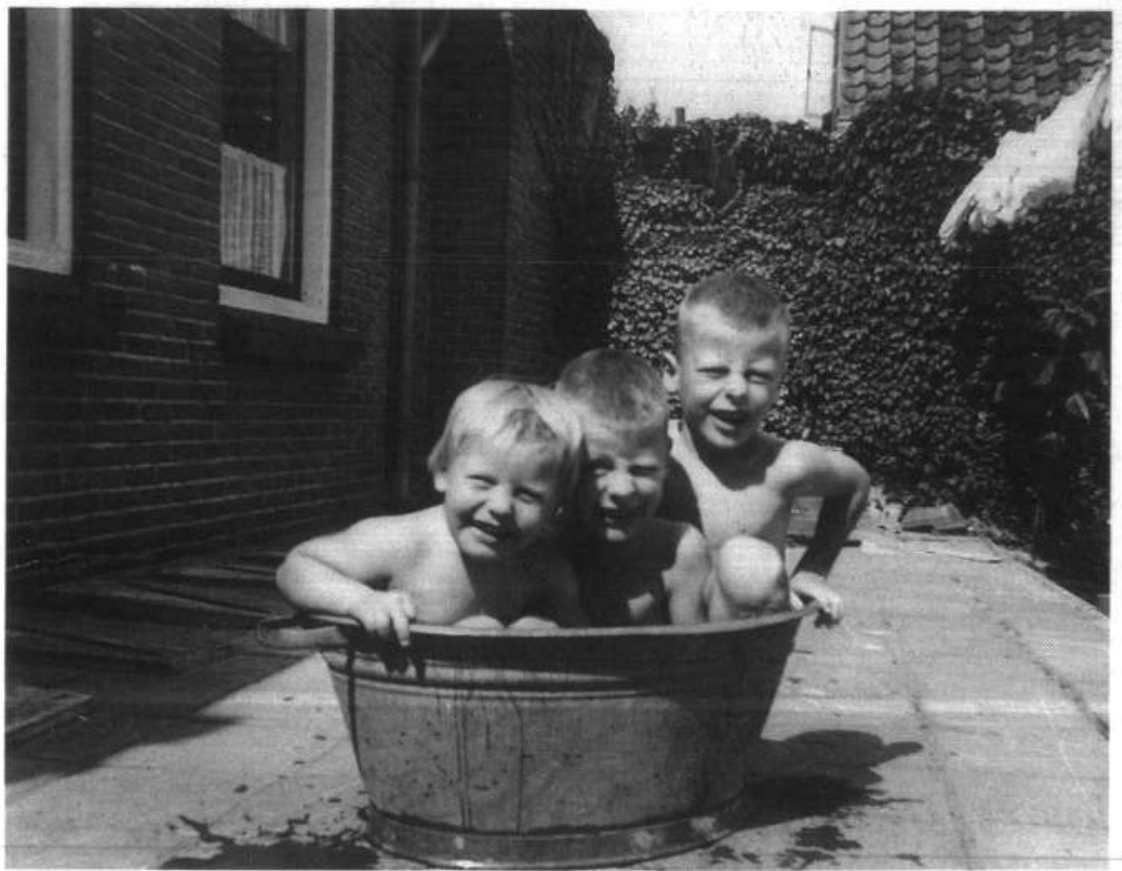


Most of us would simply not know how to alter the photographic record even if we so desired.

The manipulations that produced trick images, such as this sort of composite joke postcards of farmers posing by huge animals and vegetables, were hidden (as it were) behind the everyday veracities of Box Brownie. Obviously manipulated photographs become a species of exception which prove the evidentiary rule. Yet even with these images very often, as with Arthur Conan Doyle's naive belief in the Cottingley pictures, the scientific heritage swamped any awareness of the potential for manipulation which might have existed. On balance then, for more than a century, we have assumed, with a justice based on our own experience of the technology, that although manipulation is possible the chances are that the camera is not lying to us. It is only comparatively recently that the balance of probabilities has started to shift, and then only as far as public, published photographic images are concerned. Increasingly, we are subjecting these to a searching examination for authenticity and are finding more and more great photographs to be less than they seem.

\section{Perfect composition}

The contemporary point is that confidence in the evidential strength of the photograph was misplaced. While it was true that the apparatus recorded what was before it, there were no guarantees that such material had not been tampered with by the photographer. Lighting alone could do this and is a significant source of meaning in many images but even harder to detect is the physical manipulation of objects before the lens. For example, within 48 hours of the end of the Battle of Gettysburg, Andrew Gardner and his team were on the field making images of the aftermath. One photograph, entitled Home of a rebel sharpshooter, shows a confederate corpse sprawled in a trench. Another image, again of a dead soldier, is called $A$ sharpshooter's last sleep. This body is not so obviously a member of the Confederate Army. In fact, its quite hard to tell which side he was on but Gardner's published caption suggests he was a Union man. Both corpses are in a similar attitude lying in the lower third of the frame but the terrain is different. The 'Rebel' is in a trench while the other lies on more open ground. The 'Rebel's' rifle is propped between his legs against the rocky side of the trench whereas in the other image the rifle lies at the man's head. Experts have identified the spots as being about 40 yards apart. Others have identified the corpse as being identical in both shots. The only explanation is that Gardner was lugging a body around with him, re-costuming it as he went and even, some suggest, turning the head despite rigor mortis. ${ }^{8}$ 
The perfect composition of the image of four marines raising the Stars and Stripes on Mt. Suribachi, Iwo Jima 79 years after Gettysburg caused the editors of Life pause. The photographer, Joe Rosenthal, always claimed it was an authentic picture but it is generally agreed that the flag is a replacement for the one initially raised. The issue is: who arranged for the replacement? The suggestion is that the larger flag was prepared for hoisting at Rosenthal's instigation and the implication is that this vitiates the authenticity of the image - despite the fact that the photograph, without question, shows four 'real' marines (three of whom were to die in the battle then raging) with a 'real' flag on the actual island of Iwo Jima. These doubts did not prevent the photographer winning a Pulitzer prize in 1945 or the photograph from being used for a war bond poster, appearing on a 3c stamp and becoming the basis of a statue placed outside the Arlington National Cemetery in Washington. Manipulated or not, the image has been described as a record of 'the soul of a nation'.'

In 1950, Life published a rather different 'soul of a nation' image. The magazine commissioned Robert Doisneau to photograph the romantic French, specifically engaging in such activities as kissing on the street. The Kiss is the perfect image of young Parisians in love. A debonair man, tieless, tousled hair, scarf casually tucked into his jacket, has his arm round a lithe young woman. She leans back into the embrace as he kisses her oblivious of the people around. One of these, a gaunt-faced 'Frenchman' with beret, coat, tie and pullover, appears to be staring past the couple in studied disapproval. In fact, Doisneau treated the assignment as a photo-love-story shot and cast an actor, Jacques Carteaud, and his girlfriend, Françoise Bournet, as the couple. The stereotypical Frenchman in the beret behind them has been identified as the late Jack Costello, a Dublin auctioneer, on a motorbike pilgrimage to Rome, a bit lost in Paris looking for his travelling companion. ${ }^{10}$

These examples, chosen almost at random, deal only with the question of manipulation taking place before the camera. Beyond this, what necessarily remained outside of the frame could have profound, and clearly unknowable, effects on what was within it. Let us take one example from documentary film. In a famous sequence in his 1934 classic Man of Aran, Robert Flaherty, the 'father' of Anglo-American documentary, has his Aran family laboriously transforming a rocky field into soil using seaweed. It is an eloquent testimony to the hardiness of the islanders and their indomitable spirit in the face of grinding poverty. In his 1976 film about Flaherty on Aran, Man of Aran: How the myth as made, American documentarist George Stoney pans from the seaweed field across the headland to reveal perfectly good land nearby. Stoney tells us in commentary that when the original film was shot these fields belonged 
nineteen-fifties, although further manipulations other than cropping were not permitted.

Toilers, captioned 'Schweitzer and a carpenter watch hospital building', shows the doctor, in white shirt and pith helmet, standing before an unfinished structure. Behind him, on the structure, sits an African. Both are looking out of the frame towards something that seems to be causing them concern. They both looked worried. Silhouetted against Schweitzer's shirt is the handle of a saw and a gesturing hand. ${ }^{12}$ This is actually a composite, a real super-imposition. The arm and saw-handle are from another shot. The editors of Life, who had forbidden such practices, never knew. The deception (if it can be so called) was discovered, 30 and more years on, by Glenn Willumson going through Eugene Smith's negatives while writing his biography. ${ }^{13}$ Perhaps more significantly, Willumson also notes that, as with the smiling image of Uncle Albert, these eleven magazine pages failed to capture Smith's ambivalent attitude to Schweitzer, a tetchy and authoritarian man, who was being turned by events from a symbol of Christian charity into the very model of the paternalistic colonial. ${ }^{14}$ The essay celebrates the symbol, ignoring the politics of decolonisation.

\section{Partial evidence}

Despite all this, it would be as foolish now to doubt every image in the archive as it was, previously, naive to believe them. For instance, it has also been suggested that Robert Capa staged his Death in Spain (aka Death of loyalist soldier), the famous photograph of a Spanish loyalist militiaman at the moment of death as he runs down a slope his rifle flung wide in his right hand. The lack of uniform and the curiously ornate leather cartridge belt have been questioned. And how come, if this is the moment of death, the rifle is still being gripped? However, it was finally established in 1996 that this is indeed the last moment of loyalist militiaman and member of the anarchist trade union's youth movement, Frederico Borell Garcia from Alcoy at the battle of Cerro Muriano in defence of Cordova seven weeks into the war, on 5 September $1936 .{ }^{15}$

My point is that many of these arguments and scandals turn on quite fine questions of intervention rather than deliberate fraud and are only raised because our expectations of photography's evidentiary capacity is still, as it was at the outset, far too high. This is why, as Sekula persuasively argues, Bertillon needed the aggregate power of an archive to provide evidence of the criminal. To make a positive ID measurements and other photographs were essential, exactly because 'of an acute recognition of the inadequacies and limitations of ordinary visual empiricism'. ${ }^{16}$ In other 
words, photography offers at best partial evidence despite the richness of the data is presents. The promise of Arago and Gay-Lussac has turned out to be false. Photography does not provide unambiguous, instantly compelling data of the sort they initially envisaged - however hard it tries.

For example, no social science has made greater efforts to use the photographic image than has anthropology. And few anthropological films have tried more strenuously to produce an evidentiary record than THE AX FIGHT (1975), made among the Yanomamö of Venezuela by anthropologist Napoleon Chagnon and leading ethnographic film maker Timothy Asch. The film consists of various presentations of twelve shots taken hurriedly by Asch as a fight broke out on the afternoon of 28 February 1971 in the large Yanomamö village of Mishimishiböwie-Teri. All this we learn from titles or voice-overs in the film; that is to say (obviously), we do not learn where we are and the date and time from the photographic record itself. First we are told in an intertitle: 'That the fight began when a woman was beaten in the garden.' A voice-over idents the footage and says: 'Two women are fighting with each over (...). Bring your camera over here. It's going to start.' Then we see what a superimposed titles says is: 'The unedited record of this seemingly chaotic and confusing fight just as the field workers witnessed it on their second day in the village.' The twelve shots appear for the first time, the film makers adding only subtitles to two of them to translate what a screaming women is saying. It is clear from these, though, that despite what we first heard, the fight is not among the women but between some men. There follows a sound sequence with no pictures in which the anthropologists are heard discussing various possible explanations of the causes of the fight. The next sequence, which begins with an intertitle: 'First impressions can be misleading (...)', re-uses the footage but this time with slow-motion and super-imposed arrows to explain how the fight developed, who the main protagonists were and how they were related. This information is then formally expanded in the next sequence which represents, in diagrammatic form, the familial and lineage relationships involved. Finally the shots are re-edited, leaving out some material extraneous to the fight.

This exhaustive presentation, however, is not compelling evidence of what actually occurred. In fact, as many questions are raised as are answered. First, to be charitable, this was not Asch's finest moment as a camera-person. The main protagonist's critical blow to his major opponent with the blunt side of the axe is obscured at the edge of the frame. His felling of this opponent's brother is not seen at all. The voice-over - Chagnon - tells us that there are repeated blows but we only see one blow connect. Chagnon tells us that a woman is screaming at the other lineage but she seems to me to be yelling just as much at her own family. Chagnon tells us that a man 
is knocked unconscious but we only see him sitting on the ground seemingly wide-awake. More generally, Chagnon says the people are enraged but most just seem to be bystanders. The subtitled screaming woman at the end is said to be provoking the other side but I do not know, from the image, they can even hear her. In short, we are relying on Chagnon far, far more than would seem to be the case at first sight. Moreover, it is his interpretation which tells us how to read the incident. It is his diagram which confidently explains the implications of the fight. He explains what is at stake. He knows that, prior to this fight, 'the women have scores of their own to settle'. He determines the real reason for the fight. Above all he reads the incident as a very good example of how the Yanomamö - whom he sees, as one of his books calls them, as A fierce people - usually behave.

But, given that Asch's images offer no evidence of any of this, why should I take his word? There could be other explanations which his Yanomamö informants have not given him. Different groups - the women, say, as opposed to the men - might explain the incident differently. LéviStrauss has pointed out how common it is for anthropologists to be given different accounts of social structures by different informants exactly because social organisation is 'too complex to be formalised by means of a single model'. ${ }^{7}$ Anyway, are these Yanomamö so very fierce? Rage and anger are not so great as to cause the men to use the sharp sides of the axes. Order is restored by an unarmed man wielding nothing more than his personal authority and some feathers on his arms - or so we are told.

Let me say that I am not, of course, suggesting for a moment that Chagnon is wrong, much less that he is deliberately misrepresenting the situation for some reason. Rather, my point is simply that all the apparatus of this film - the repeated footage, the arrows, the diagrams, the way in which the film-making process is revealed rather than remaining hidden as it usually does - is insufficient to compel support for Chagnon's version of events. While the footage does not in anyway contradict him, nevertheless the photographic record is too ambiguous for his to be the only available reading. As Bill Nichols, considering this same film, has written:

'We can see with our own eyes and ears what the camera and tape recorder has provided for us. It is already more than a chronicle or assembly of data, much more. It has the same mix of transparent obviousness (often absent from data) and impenetrability (often abundant in data) that forms of lived encounter also possess. ${ }^{18}$

Nevertheless, the screen does not 'yield facts as they are normally regarded or encountered, in service to subsequent interpretation'. Thus, although ' $(w)$ ith film, rigorous description attains a qualitatively distinct level (...) 
the filmed record of actual events is not quite as firm a guarantee of what really happened as we may at first thought.'

The problem with THE AX FIGHT is not Chagnon's commentary but the fact that he is relying on the scientific heritage of the camera to make a strong claim - a very strong claim - that he is presenting evidence of the real world. However, the claim is built on the sands of inference rather than the rock of objectivity. To make any sense of the images, Chagnon takes what Umberto Eco might call 'an inferential walk' and comes up with a monological account of the data. The ability of the material as evidence to sustain such an account is never questioned. We, like strangers gazing at the photo of Uncle Albert and thinking him a friendly soul, are told that these are fierce tribal people and that this footage is authentic evidence of that ferocity.

\section{Continuum of authenticity}

However, as we have seen with the examples I have given, the authenticity of the photographic image is complex. It is a real Civil War corpse, but that is not where it fell nor how it was dressed. It is a real Stars and Stripes but it comes to be in the frame because of the photographer rather than because of the military. It is real kiss in a real street but the lovers are actors - actors who happen to be lovers in what I suppose we must call 'real life' but would not have been in that place at that time had the photographer not asked them to be. It is a real tribal fight but its causes are not clear, its course is confused and its outcome is obscure. There is, in fact, within any one photographic image a 'continuum of authenticity' - if you will - a complex range of relationships with real.

Consider a publicity photograph from 1964, showing a television production team. It was taken on the tarmac at London airport. Camera cars and the camera crews with their equipment occupy the middle ground. In front of them film editing machines, editing tables and office desks have been placed. Editors, researchers, secretaries and producer/directors sit and stand around. In the background is a small plane. Although everything you see was, in fact, in front of the lens, the World in Action did not actually live on the south-side apron at Heathrow, which is where the shot was taken. Since I was a member of this team I know that we had offices, with walls, ceilings and windows - all the usual appurtenances - in Granada's Soho building. Our telephones, contrary to what is shown in the photograph, were connected. But - of course - any viewer could work that out. You could, in effect, compare this photograph with what you know and understand of offices, television production units and advertising and publicity shots. 
Some of the information you use to work out what this image means comes from your own experience: how offices really are arranged, for example. Further information helping you understand this image also comes from your own experience but not of the real world so much as of other images, other representations: in this case, what a publicity shot is, for example. Umberto Eco describes this process of discovering what a representation means as a sort of 'testing' against experience. It's like taking a mental walk into the representation, the image, the text - whatever it may. We take these walks, Eco suggests, for the purpose of making inferences and it is these multitudinous inferences which collectively become our understanding of what the representation means. We squeeze meaning out of the representation via such inferences and in so doing we - dread word 'deconstruct' it. ${ }^{20}$

In the case of most photographs as well as all documentaries and ethnographic films, the basic inferential purpose is to test, as it were, for authenticity. But between the obvious falseness of some elements of the image and, let's call it for the moment, the common-sense authenticity of other elements, there are further ambiguities. The plane, for example, certainly belonged to Granada but was actually more or less Mr. Sydney's, as Lord Bernstein was called within the company. It was never to my knowledge routinely used by World In Action. In fact, we all tried to avoid it because it was slow, uncomfortable and generally inconvenient. Point is you could make as many inferential walks as you liked but you would know none of that from this image. In other words, some elements are easier to deconstruct as either authentic or inauthentic than are others.

There is, in fact, within this one photograph a 'continuum of authenticity' - if you will - a complex range of relationships with real world. And that is typical of all photographs. The concept of the 'continuum of authenticity' leads me to suggest that photographs and factual film - news, documentary, ethnographic film, photographic images in general - can only be considered as evidence of the real world in limited and complex ways - more limited and more complex than we commonly allow. Certainly in ways more limited than our everyday practice of journalism, of television, of ethnographic film even, allows.

\section{The veracities of the box brownie}

We have a pressing reason to engage with these limitations and complexities. Let's assume we are all sophisticated enough to understand that photographs are not simply evidence of the world, the problem now is that such sophistication will no longer serve us. Take a photograph from 
the (London) Sun newspaper of a monk and his girl friend. Alas for the Sun, he was actually snapped wearing jeans and a t-shirt. But, undeterred, the Sun simply scitexed in - digitised - a habit for him. When challenged the Sun said: 'We have superimposed the monk's habit to make it clear to readers that the story is about a monk.' For me, this image, potentially reveals that these days, believing in photographs as evidence of the real world is a rather hazardous business.

I am absolutely certain that the illusion of photography having some sort of an umbilical cord to the real world is doomed. There is a steady public drip, drip of images undermining Arago's scientism. Now Sly Stallone and Groucho Marx can join Churchill, Stalin and Roosevelt at Yalta. Of course, we could always do this crudely by superimposition but, as FORREST GUMP shows, now Sly and Groucho can walk and talk in such images. It seems reasonable to suppose that people will begin to understand that such special effects are in general destroying photography's claim on the real. The public are being endlessly shown that digitally manipulated images are indistinguishable from more straightforward traditional photography. Thus Princess Di can be made to advertise jeans in the Sun. What, in the long term, do such games do for the supposedly real photographs of the supposedly real $\mathrm{Di}$ in the public mind? And no longer do the family snaps at Coney Island remain inviolate either. Today, firms will doctor your family album, divorced spouses removed and so on, with an ease and an undetectability that the photo-editors of the Great Soviet Encyclopaedia would have died for. In this case an entire branch of the family seem to have been struck out. Of course, the technology to do this sort of thing on your PC is already to hand, a little crudely perhaps but that crudity is temporary.

I find all of this potentially quite liberating for the realist image because it is being freed of a burden it could never carry. But, as the illusion fades, we need a new social understanding of the cultural status of the photographic image. I do not want digitalisation, much less post-modern philosophy, to throw the baby out with the bath water. For, despite all this, something of the realist project, the veracities of the box brownie, remains. Now we must be sophisticated enough not to believe a photographic image is like a window on the world, a window unmarked by the photographer's finger-prints. But to acknowledge the presence of the photographer is not necessarily to deny totally that you can still see something of the world. You can. I would describe this as making a weak claim for the photograph as evidence, adopting (as it were) 'a mild realist position'.

To take such a position, however, is to move a long way from the traditional view we have of photographic technologies. Such a move has considerable implications for how our audio-visual culture works. If we stop 
1976 [?] Groningen. Bron: Collectie Van Haarlem

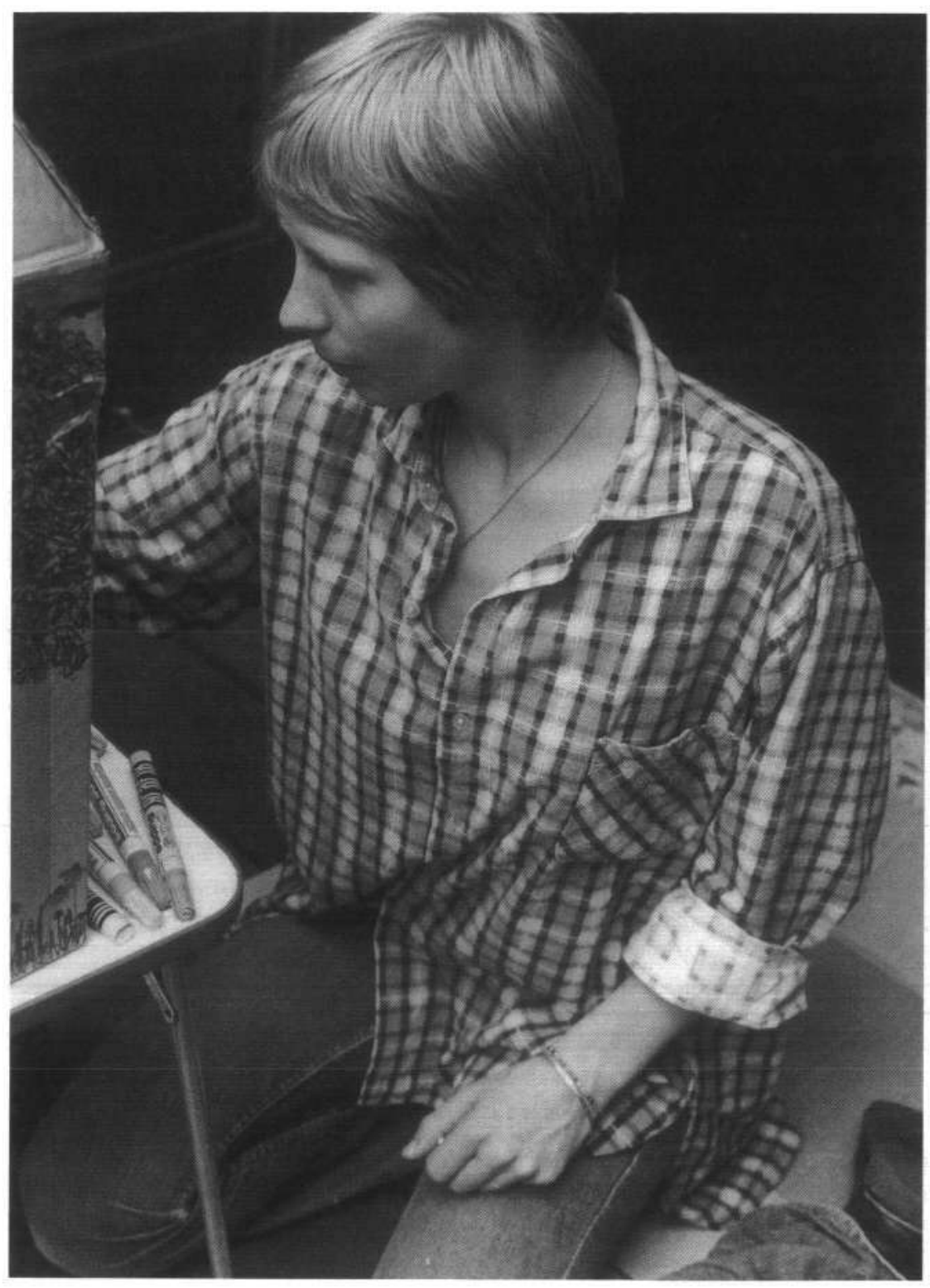

making strong claims for photos as evidence, in effect we transfer the onus of the claim on the real from the image to the viewer. That is to say, we stop pretending authenticity - truth, even - can be found within the frame. Instead we rely on our inferential walks to test for authenticity and truth. We would be moving the legitimacy of the realist image from representation - the screen or the print - where nothing can be guaranteed to reception - by the audience or the viewer - where nothing need be guaranteed. 
Robert Fairthorne, a radical film critic, wrote in 1933 that " actuality" is not a fundamental property' of the photographic image. He said it was like fast-or slow-motion. To understand them you needed to have prior knowledge of speed in the real world. ${ }^{2 t}$ More generally then, to understand what is authentic in the image, a general understanding of the real world which, of course, we all have - is needed. The illusion that the photograph provides simple, compelling evidence about the real world is ending. But it is only the illusion that photographs are somehow automatic - scientific reflections of the world which should be abandoned. In its place must come the idea that the photograph can provide evidence of the real world but in a way more akin to the evidence provided by painting or writing. We must finally acknowledge the photographer as a subjective presence even while the science of his camera allows us to continue to test, in a qualitative way, for authenticity.

If our common-sense, everyday understanding of the camera's ability to capture images of the world is to be maintained in this environment, then a weak realist position which throws the onus of evaluating the images' authenticity onto the viewer might just be sustainable. It is clear that the traditional Arago/Gay-Lussac 'scientific-evidence' claim, always dubious, now cannot be maintained at all. Andrew Bennett's attempt to legislate in Parliament for the strong realist position is quixotic.

\section{Noten}

I J.M. Eder, History of photography, New York 1972, p. 238.

2 Idem, p. 242.

3 Hansard, 30 maart 1994, p. 951.

4 C. Peirce, Collected papers (vol. 2), Cambridge 1965, p. 143 and p. 159.

5 B. Edelman, Ownership of the image. Elements for a Marxist theory of law, Londen 1974 , p. 44 e.v.

6 A. Sekula, 'The body and the archive', in: October, nr. 39, winter 1986, p. I8.

7 Hansard, 30 maart 1994, p. 951.

8 M. Fulton, Eyes of time. Photojournalism in America, New York 1988, p. 23-28.

9 Idem, p. 160-161.

10 P. Lennon, 'It started with a kiss', in: The Guardian, 6 januari 1993.

II G. Willumson, W. Eugene Smith and the photographic essay, Cambridge 1992, p. $248-50$.

12 Anonymus, 'A man of mercy', in: Life, vol. 37 nr. 20, 5 november 1954, p. 16I.

13 G. Willumson, W. Eugene Smith and the photographic essay, p. 211-213.

14 Idem, p. 193-203.

15 The Observer, I september, 1996.

16 A. Sekula, 'The body and the archive', p. 18.

17 C. Lévi-Strauss, Structural anthropology, Londen 1968, p. 134. 
I8 B. Nichols, 'What really happened. THE AX FIGHT reconsidered', in: Media International Australia, nr. 82, november 1996, p. 8.

I9 Idem, p. 8-9.

$20 \mathrm{U}$. Eco, The role of the reader. Explorations in the semiotics of texts, Bloomington 1984 .

2I R. Fairthorne, 'The principles of the film, in: D. MacPherson (ed.), Traditions of independence, Londen 1980 , p. 171 . 